\title{
Community ecology of the metazoan parasites of the Atlantic thread herring, Opisthonema oglinum (Lesueur, 1818) (Actinopterygii: Clupeidae) from the Sepetiba Bay, Rio de Janeiro, Brazil
}

\author{
L. Chaves ${ }^{a}$ (i) and F. Paschoal $*$ (1) \\ áaboratório de Parasitologia Animal, Centro de Pesquisas em Biologia - CEPBio, Universidade Castelo Branco - UCB, \\ Av. Santa Cruz, 1631, Realengo, CEP 21710-231, Rio de Janeiro, RJ, Brasil \\ *e-mail: paschoalfabiano@gmail.com
}

Received: October 9, 2019 - Accepted: January 12, 2020 - Distributed: May 31, 2021

\begin{abstract}
This study aimed to evaluate the parasitic fauna of Opisthonema oglinum (Lesueur, 1818) from Southeastern Brazil. Between September 2017 and March 2018, a total of 100 specimens of O. oglinum from the Sepetiba Bay, Rio de Janeiro, Brazil (22 $54^{\prime}$ S, $\left.43^{\circ} 34^{\prime} \mathrm{W}\right)$ were examined. Ninety one specimens of $O$. oglinum were parasitized by at least one species of metazoan with a mean of $5.84 \pm 7.98$ parasites/fish. Seven species were collected: 2 digeneans, 2 monogeneans, 2 copepods and 1 nematode. The digenean Parahemiurus merus (Linton) was the most abundant and dominant species, representing $43 \%$ of metazoan parasites collected. The parasite species richness was positively correlated with the total length of the hosts. Only Neobomolochus elongatus Cressey showed a positive correlation between host's total length and parasite prevalence. The mean parasite species diversity was not correlated with host's total length, but significant differences among the mean parasite diversity between males and females was observed. Opisthonema oglinum represents a new host record for Caligus mutabilis Wilson, Hysterothylacium sp. and Cribomazocraes travassosi Santos and Kohn. The copepod N. elongatus is recorded for the first time on the Brazilian coast.
\end{abstract}

Keywords: Clupeidae, Brazilian marine fish, parasite, community structure.

\section{Ecologia da comunidade dos metazoários parasitos da sardinha bandeira Opisthonema oglinum (Lesueur, 1818) (Actinopterygii: Clupeidae) da Baía de Sepetiba, Rio de Janeiro, Brasil}

\begin{abstract}
Resumo
Este estudo teve como objetivo avaliar a fauna parasitária de Opisthonema oglinum (Lesueur, 1818) do Sudeste do Brasil. No período entre setembro de 2017 e março de 2018, um total de 100 espécimes de $O$. oglinum provenientes da Baía

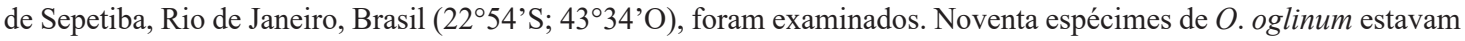
parasitados por pelo menos uma espécie de metazoário com média de 5,84 7 7,98 parasitos/peixe. Sete espécies foram coletadas: 2 digenéticos, 2 monogenéticos, 2 copépodes e 1 nematoide. O digenético Parahemiurus merus (Linton) foi à espécie mais abundante e dominante, representando $43 \%$ dos metazoários parasitos coletados. A riqueza parasitária foi correlacionada com o comprimento total do hospedeiro. Apenas Neobomolochus elongatus Cressey apresentou correlação positiva entre o comprimento total do hospedeiro e a prevalência parasitária. A diversidade média de espécies de parasitos não apresentou correlação com o comprimento total do hospedeiro, mas foram observadas diferenças significativas entre a diversidade média de parasitos entre machos e fêmeas. Opisthonema oglinum representa um novo registro de hospedeiro para Caligus mutabilis Wilson, Hysterothylacium sp. e Cribomazocraes travassosi Santos and Kohn. O copépode N. elongatus é registrado pela primeira vez na costa Brasileira.
\end{abstract}

Palavras-chave: Clupeidae, peixe marinho brasileiro, parasito, estrutura da comunidade.

\section{Introduction}

The Sepetiba Bay is considered one of the most important aquatic ecosystems in the state of Rio de Janeiro, presenting a considerable amount of organic input in suspension, dissolved salts and high concentration of planktonic algae which made their waters suitable for many marine species (Araújo et al., 1997, 1998).
Around 97 species of fishes distributed in 70 genera and 38 families have been recorded in this bay, but with the increasing development of the industrial complex and population density in the region, some changes in water quality and local biota have been reported (Pfeiffer et al., 1985; Araújo et al., 1998). 
The actinopterygians of the family Clupeidae have a considerable value to commercial fishery in many parts of the world. Currently this family is represented by 197 species distributed in 55 genera around the world, most of these found in tropical regions, mainly in marine coastal zones and some in freshwater (Nelson, 2006; Froese and Pauly, 2019).

The Atlantic thread herring, Opisthonema oglinum (Lesueur) is a marine pelagic fish, found in harbors and shallow coastal areas from the Gulf of Maine (USA) to the southern Brazil, feeding on planktonic organisms, small fishes, and occasionally crabs and shrimps (Froese and Pauly, 2019). It is one of the most commercially important fish species in the South Atlantic Ocean off Brazil, with annual catches being over 5000-6000 t, and occupies an important position in industrial fisheries along the Caribbean Waters and Gulf of Mexico (González-Cabellos and Mengual-Izquierdo, 1995; Vega-Cendejas et al., 1997; Feltrim and Schwingel, 2005; Lessa et al., 2008).

In Brazil, studies regarding the metazoan parasite community of clupeids have been performed by Luque et al. (2000), on the parasitic fauna of Harengula clupeola (Cuvier), by Tavares et al. (2004) on Brevoortia aurea (Spix and Agassiz) and more recently by Moreira et al. (2015) on Sardinella brasiliensis (Steindachner), all of them from the coastal zone of the State of Rio de Janeiro. However, despite being one of the most important species in artisanal fishing in Brazil, studies on the parasitic fauna of $O$. oglinum are still incipient. So far only three species of parasites have been recorded in this fish in Brazilian waters: Acusicola brasiliensis Amado \& Rocha (Copepoda), Parahemiurus merus (Linton) (Digenea) and Callitetrarhynchus gracilis (Rudolphi) (Cestoda) (Fábio, 1988; Palm, 1997; Luque and Tavares, 2007).

Considering the scarcity of studies on the parasitic fauna of $O$. oglinum, in the present paper, we analyzed the composition and structure of the metazoan parasite community of $O$. oglinum from the Sepetiba Bay, Rio de Janeiro, Brazil.

\section{Material and Methods}

\subsection{Fish collection and identification}

Between September 2017 and March 2018, 100 specimens of $O$. oglinum were necropsied, from the Sepetiba bay (22 $54^{\prime}$ 'S, $\left.43^{\circ} 34^{\prime} \mathrm{W}\right)$, Rio de Janeiro, Brazil, to study their community of metazoan parasites communities. Fish were collected by local fishermen and purchased at fish markets. They were identified according to Figueiredo and Menezes (1978); the nomenclature and classification were updated according to FishBase (Froese and Pauly, 2019).

\subsection{Analyses of parasites and deposited specimens}

The analysis included only parasite species with prevalence higher than 10\% (Bush et al., 1990). The variance-to-mean ratio of parasite abundance (index of dispersion) and the discrepancy index, computed using the program Quantitative Parasitology 3.0 (Rózsa et al., 2000), were used to detect distribution patterns of the infrapopulations (Poulin, 1993). The dominance frequency (percentage of infracommunities in which either parasite species was dominant) and the relative dominance (number of specimens of one species/total number of specimens of all species in the infracommunity) of each parasite species were calculated according to Rohde et al. (1995). The parasite species diversity was calculated using the Brillouin index $(H)$, because each fish analyzed corresponded to a fully censused community (Zar, 1996). The Spearman's rank correlation coefficient $r_{s}$ was calculated to determine possible correlations between the total length of hosts and parasite abundance. Pearson's correlation coefficient $r$ was used to indicate the relationship between the host's total length and parasite prevalence, with previous arcsine transformation of the prevalence data (Zar, 1996). The effect of host sex on abundance and prevalence of parasites was tested using the $Z_{c}$ (normal) approximation to the Mann-Whitney test and the Fisher exact test, respectively. The probable variation of diversity in relation to host sex (Mann-Whitney test) and to host total length (Spearman's rank correlation coefficient) was tested. Possible interspecific association between concurrent species was determined using the chi-square test. Possible covariation among the abundance of concurrent species was analyzed using the Spearman's rank correlation coefficient. The ecological terminology used follows Bush et al. (1997). Statistical significance level was evaluated at $p \leq 0.05$.

Voucher specimens of helminths were deposited in the Helminthological Collection of Institute Oswaldo Cruz (CHIOC), Rio de Janeiro, Brazil; copepods were deposited in the scientific collection of the Museum of Zoology (MZUSP), University of São Paulo, Brazil.

\section{Results}

The average total length of the fish was 12-25.5 $(19.2 \pm 2.68) \mathrm{cm}$, and the weight was $19-106(78.5 \pm 29.28) \mathrm{g}$. The average total length of male $(18.6 \pm 2.71, n=69)$ and female $(20.5 \pm 2.10, n=31)$ fishes in the studied sample were significantly different $(t=-3.408, p=0.005)$.

\subsection{Component community}

Seven species of metazoan parasites were collected (Table 1). Opisthonema oglinum is a new host record for Caligus mutabilis Wilson, Hysterothylacium sp. and Cribomazocraes travassosi Santos and Kohn. The digenetic trematode Parahemiurus merus was the most abundant and dominant species, representing $43 \%$ of metazoan parasites collected, with greatest values of mean relative dominance and frequency of dominance (Table 2). The copepod Neobomolochus elongatus Cressey was the most prevalent species (Table 1).

Adult endoparasites represented $67.29 \%$ of all parasites collected, ectoparasites totalizing to $32.36 \%$ and larval endoparasites made up $0.34 \%$. All parasites of $O$. oglinum had the typical aggregated pattern of distribution, except the copepod N. elongatus that showed dispersion index lower than 1 , indicating a uniform pattern of distribution (Table 3 ). 
Table 1. Prevalence, mean intensity, mean abundance, and site of infection/infestation of metazoan parasites of Opisthonema oglinum from the Sepetiba Bay, Rio de Janeiro, Brazil.

\begin{tabular}{|c|c|c|c|c|}
\hline Parasites & Prevalence (\%) & Mean intensity & Mean abundance & $\begin{array}{c}\text { Site of infection/ } \\
\text { infestation }\end{array}$ \\
\hline \multicolumn{5}{|l|}{ Digenea } \\
\hline $\begin{array}{l}\text { Parahemiurus merus } \\
\text { CHIOC N } 40071\end{array}$ & 43 & $7.09 \pm 8.79$ & $2.99 \pm 6.65$ & Stomach \\
\hline $\begin{array}{l}\text { Myosaccium opisthonemae } \\
\text { CHIOC N } \mathrm{N}^{\circ} 40073\end{array}$ & 22 & $4.27 \pm 5.25$ & $0.94 \pm 3.00$ & Stomach \\
\hline \multicolumn{5}{|l|}{ Monogenea } \\
\hline $\begin{array}{l}\text { Cribomazocraes travassosi } \\
\text { CHIOC N } 40072\end{array}$ & 20 & $1.15 \pm 0.366$ & $0.23 \pm 0.48$ & Gills \\
\hline $\begin{array}{l}\text { Mazocraeoides opisthonema } \\
\text { CHIOC N }{ }^{\circ} 40070 \\
\text { Nematoda }\end{array}$ & 30 & $2.7 \pm 1.93$ & $0.81 \pm 1.62$ & Gills \\
\hline $\begin{array}{l}\text { Hysterothylacium sp. (larval) } \\
\text { CHIOC N } 38716 \\
\text { Copepoda }\end{array}$ & 2 & 1 & $0.02 \pm 6.65$ & Mesenteries \\
\hline $\begin{array}{l}\text { Neobomolochus elongatus } \\
\text { MZUSP N } 40233\end{array}$ & 60 & $1.31 \pm 0.72$ & $0.79 \pm 0.85$ & Gills \\
\hline $\begin{array}{l}\text { Caligus mutabilis } \\
\text { MZUSP No } 40230\end{array}$ & 3 & 1 & $0.03 \pm 0.17$ & Opercular cavity \\
\hline
\end{tabular}

Table 2. Frequency of dominance and mean relative dominance of metazoan parasites of Opisthonema oglinum from the Sepetiba Bay, Rio de Janeiro, Brazil.

\begin{tabular}{lccc}
\hline \multicolumn{1}{c}{ Parasites } & Frequency of dominance & $\begin{array}{c}\text { Frequency of dominance } \\
\text { shared with one or more } \\
\text { species }\end{array}$ & $\begin{array}{c}\text { Mean relative } \\
\text { dominance }\end{array}$ \\
\hline Parahemiurus merus & 34 & 7 & $0.310 \pm 0.400$ \\
Neobomolochus elongatus & 18 & 12 & $0.227 \pm 0.375$ \\
Mazocraeoides opisthonema & 11 & 2 & $0.097 \pm 0.256$ \\
Myosaccium opisthonemae & 10 & 2 & $0.090 \pm 0.251$ \\
Cribomazocraes travassosi & 3 & 6 & $0.054 \pm 0.188$ \\
Hysterothylacium sp. (larval) & 1 & - & $0.010 \pm 0.100$ \\
\hline
\end{tabular}

Table 3. Values of variance to mean ratio of parasite abundance (ID) and index of Discrepancy (D) of metazoan parasites of Opisthonema oglinum from the Sepetiba Bay, Rio de Janeiro, Brazil.

\begin{tabular}{lcl}
\hline \multicolumn{1}{c}{ Parasites } & ID & D \\
\hline Parahemiurus merus & 14.682 & 0.811 \\
Neobomolochus elongatus & $0.924^{*}$ & $0.513^{*}$ \\
Mazocraeoides opisthonema & 3.209 & 0.805 \\
Myosaccium opisthonemae & 9.603 & 0.889 \\
Cribomazocraes travassosi & 1.141 & 0.814 \\
\hline
\end{tabular}

\footnotetext{
*significant values.
}

The host's total length was not correlated with the abundance of any parasite species. Only N. elongatus showed positively correlation between host's total length and parasite prevalence $\left(r_{s}=0.2605, p=0.008\right)$. The sex of hosts did not influenced prevalence and abundance of any parasite species.

\subsection{Infracommunities}

Ninety one specimens (91\%) of O. oglinum were parasitized by at least one parasite species. A total of 584 individual parasites were collected, with mean of $5.84 \pm 7.98$ parasites/fish. The host's total length was not correlated with parasite abundance $\left(r_{s}=0.181, p=0.071\right)$, but positive correlations were detected between the host's total length and parasite species richness $\left(r_{s}=0.212, p=0.034\right)$. Twenty-nine hosts (29\%) showed infection with one parasite species, and $38(38 \%), 21(21 \%)$ and $3(3 \%)$, had multiple infections with 2, 3, 4 parasite species, respectively. Mean parasite species diversity $(H=0.330 \pm 0.365)$ was not correlated with host's total length $\left(r_{s}=0.098, p=0.353\right)$ but there were significant differences in the parasite diversity 
Table 4. Concurrent species pairs of ectoparasites in Opisthonema oglinum from the Sepetiba Bay, Rio de Janeiro, Brazil.

\begin{tabular}{lcrrr}
\multicolumn{1}{c}{ Parasites } & \multicolumn{1}{c}{$\boldsymbol{x}^{2}$} & \multicolumn{1}{c}{$\boldsymbol{p}$} & \multicolumn{1}{c}{$\boldsymbol{r}_{s}$} & $\boldsymbol{P}$ \\
\hline Mazocraeoides opisthonema - Cribomazocraes travassosi & 1.190 & 0.2752 & $<0.0938$ & 0.3531 \\
Neobomolochus elongatus - M. opisthonema & 0.198 & 0.656 & 0.0828 & 0.4127 \\
C. travassosi - N. elongatus & 0.378 & 0.535 & $<0.0897$ & 0.3749 \\
\hline
\end{tabular}

$\left(\chi^{2}\right)$ values of Chi-square test; $(r)$ values of Spearman's rank correlation coefficient. $(p)$ significant level.

observed between male $(H=0.240 \pm 0.292)$ and female $(H=0.512 \pm 0.430)$ fish $\left(Z_{c}=-1,946, p=0.025\right)$.

Parasite infracommunities were separated in two groups - ectoparasites (monogeneans and copepods) and adult endoparasites (digeneans) - to determine possible interspecific associations. Larval stages were not included in this analysis because the only species found, i.e., Hysterothylacium sp., showed prevalence lower than $10 \%$. Among the digeneans, the pair species Myosaccium opisthonemae-Parahemiurus merus did not share significant association and covariation $\left(\chi^{2}=1.439, p=0.230 ; r_{s}=0.086, p=0.395\right)$. The infracommunities of ectoparasites had three pairs of species with prevalence higher than $10 \%$, but they did not presented positive correlation and covariation (Table 4).

\section{Discussion}

The present study showed that the digenetic trematode $P$. merus was the most dominant species in the parasitic community of $O$. oglinum. The dominance of digenean endoparasites has been described for several parasite communities of marine fish from the coastal zone of southeastern Brazil (Luque et al., 1996, Takemoto et al., 1996, Knoff et al., 1997, Luque and Chaves, 1999; Silva et al., 2000; Luque and Alves, 2001; Tavares and Luque, 2004; Moreira et al., 2015). Among some characteristics cited by the authors to explain this pattern, the wide food spectrum of demersal fish may be the main factor, as it facilitates the consumption of potential intermediate hosts of acanthocephalans, digeneans and nematodes, which may increase the presence of endoparasites in these fish.

The aggregate habits and the high population density formations of the herrings may facilitate the transmission of some ectoparasites with direct life cycle, such as copepods and monogeneans (Tavares et al., 2004). The monogenean Cribomazocraes travassosi Santos and Kohn was originally described parasitizing the gills of Harengula clupeola (Cuvier) from the coast of Rio de Janeiro (Santos and Kohn, 1992). Later, Moreira et al. (2015) recorded this species parasitizing the gills of $S$. brasiliensis, also from the coast of Rio de Janeiro, however with a low prevalence of $3 \%$. In the present study, C. travassosi is recorded for the first time parasitizing the gills of O. oglinum, however with a prevalence of $20 \%$.

The copepod Neobomolochus elongatus, species with the highest prevalence of the metazoan parasites collected, is the only representative species of the genus Neobomolochus Cressey, and was described parasitizing the eyes of O. oglinum in the North Atlantic Ocean, more specifically on the coast of the "West Indies" and Florida.
Currently, 18 species of the family Bomolochidae Claus have been recorded in the Brazilian coast, seven belonging to the genus Bomolochus, followed by the genera Acantholochus (3 spp.), Ceratocolax (2 spp.), Hamaticolax (2 spp.), Orbitocolax (2 spp.), Nothobomolochus (1 sp.) and Unicolax (1 sp.) (Luque et al., 2013). Thus the present study expands the distribution of the genus Neobomolochus, now also present in the Southern Atlantic Ocean, being N. elongatus recorded for the first time in the Brazilian coast.

The parasitic community of $O$. oglinum had the typical aggregate distribution pattern, except for $N$. elongatus which presented a dispersion index of less than 1 , thus indicating a uniform distribution pattern, which is not a common occurrence in parasites. According to Von Zuben (1997) there are three factors that can lead to a uniform pattern of distribution: (1) mortality of parasites; (2) density dependent processes; and (3) the mortality of the host induced by the parasite (mortality rate positively correlated with parasite charge).

In the present study, the copepod $N$. elongatus showed a positive correlation between parasitic prevalence and the total length of O. oglinum. According to Cressey et al. (1983) variations in copepod infestations in relation to host length are mainly related to mechanical factors. According to the authors, females of some copepods only remain in the host if they have a size and width that is compatible with the parasites fixation organs. Thus the growth of host gill filaments may be related to the presence or absence of the parasite in the host, as parasitism would only occur in hosts with specific size gill filaments.

Comparing the parasitic richness (at component community level) of clupeid fish from the coast of Rio de Janeiro, S. brasiliensis ( $\mathrm{N}=11$ ) (Moreira et al., 2015) presented a higher number of parasite species than O. oglinum $(\mathrm{N}=7)$ in the present study, and than H. clupeola $(\mathrm{N}=6)$ (Luque et al., 2000), B. aurea $(\mathrm{N}=5)$ (Tavares et al., 2004). However, in the present study, parasitic richness was correlated with total host length, a correlation not previously detected in studies on parasitic clupeid communities off the coast of Rio de Janeiro. According to some authors, larger hosts are expected to harbor richer parasitic fauna, mainly because they provide a greater variety of niches, support a larger absolute number of parasites, and often undergo ontogenetic changes in their diet, suggesting that they may be exposed to a greater number of intermediate and/or paratenic hosts (Poulin, 1995, 2001a; Bush et al., 2001; Tavares et al., 2005).

The correlations between host sex and abundance and prevalence in parasitic communities of clupeid fish off the 
coast of Rio de Janeiro suggest a heterogeneous pattern of results. In the present study, the absence of correlations between host gender and the prevalence and abundance in the parasitic community of $O$. oglinum was observed, which was also reported by Luque et al. (2000) and Moreira et al. (2015) in S. brasiliensis. However, different patterns have already been observed in other clupeid fish off the coast of Rio de Janeiro (Luque et al., 2000; Tavares et al., 2004). According to Poulin (1995), the altered hormone levels may be associated with this pattern, since high levels of testosterone may cause immunosuppression in males, which could lead to higher parasite susceptibility in males than females.

The lack of association between parasite species in $O$. oglinum is a condition already observed in other Neotropical marine fish (Tavares and Luque, 2004; Moreira et al., 2015), and according to Rohde et al. (1995) this is a common pattern in most marine fish studied. However, positive and negative associations between helminth species should only be considered valid when tested under experimental conditions, as they can provide strong evidence that interactions between species exist and act on community structure (Rohde et al., 1995; Poulin, 2001b). For Rohde et al. (1995) marine fish parasite communities constitute a complex of confused and unsaturated species, thus diverging from other host groups. The parasitic community of $O$. oglinum can be included as another example of these communities.

\section{Acknowledgements}

We wish to thanks João Victor Couto and Luana Benicio, from the Universidade Castelo Branco, Rio de Janeiro (Brazil), for their help with material collecting fish and parasitological examination. We are also grateful to Juliana Moreira, researcher of the Group of studies in Biodiversity and Animal Biology of the Universidade Castelo Branco, Rio de Janeiro (Brazil), for revising this paper. Leticia Chaves was supported by a student fellowship from Universidade Castelo Branco, Rio de Janeiro (Brazil).

\section{References}

ARAÚJO, F.G., CRUZ-FILHO, A.G., AZEVEDO, M.C.C., SANTOS, A.C.A. and FERNANDES, L.A.M., 1997. Estrutura da comunidade de peixes jovens da margem continental da Baía de Sepetiba, RJ. Acta Biologica Leopoldensia, vol. 19, no. 1, pp. 61-83.

ARAÚJO, F.G., CRUZ-FILHO, A.G.D., AZEVÊDO, M.C.C.D. and SANTOS, A.C.A.S., 1998. Estrutura da comunidade de peixes demersais da baía de Sepetiba, RJ. Brazilian Journal of Biology = Revista Brasileira de Biologia, vol. 58, no. 3, pp. 417-430. http:// dx.doi.org/10.1590/S0034-71081998000300007.

BUSH, A.O., AHO, J. and KENNEDY, C.R., 1990. Ecological versus phylogenectic determinants of helminth parasite community richness. Evolutionary Ecology, vol. 4, no. 1, pp. 1-20. http:// dx.doi.org/10.1007/BF02270711.
BUSH, A.O., FERNÁNDEZ, J.C., ESCH, G.W. and SEED, J.R., 2001. Parasitism: the diversity and ecology of animal parasites. Cambridge: Cambridge University Press, 566 p.

BUSH, A.O., LAFFERTY, K.D., LOTZ, J.M. and SHOSTAK, A.W., 1997. Parasitology meets ecology on its own terms: margolis et al. revisited. The Journal of Parasitology, vol. 83, no. 4, pp. 575-583. http://dx.doi.org/10.2307/3284227. PMid:9267395.

CRESSEY, R.F., COLLETTE, B.B. and RUSSO, J.L., 1983. Copepods and scombrid fishes: A study in host-parasite relationships. Fish Bulletin, vol. 81, no. 2, pp. 227-265.

FÁBIO, S.P., 1988. Sobre três Hemiuridae parasitos de peixes do litoral do Estado do Rio de Janeiro. Arquivos da Universidade Federal Rural do Rio de Janeiro, vol. 7, pp. 157-160.

FELTRIM, M.C. and SCHWINGEL, P.R., 2005. Opisthonema oglinum. In: M.C. CERGOLE, A.O. ÁVILA-DA-SILVA and C.L.D.B. ROSSI-WONGTSCHOWSKI, eds. Análise das principais pescarias comerciais da região Sudeste-Sul do Brasil: dinâmica populacional das espécies em explotação. São Paulo: EDUSP, pp. 112-115. Série documentos REVIZEE: SCORE SUL.

FIGUEIREDO, J.L. and MENEZES, N.A., 1978. Manual de peixes marinhos do sudeste do Brasil II Teleostei. São Paulo: Museu de Zoologia, $110 \mathrm{p}$.

FROESE, R. and PAULY, D. 2019 [viewed 8 October 2019]. FishBase. World Wide Web electronic publication [online]. Available from: http://www.fishbase.org

GONZÁLEZ-CABELLOS, L.W. and MENGUAL-IZQUIERDO, A., 1995. Age And Growth Of The Atlantic Thread Herring, Opisthonema Oglinum (Lesueur, 1818) (Teleostei: Clupeidae), Of Margarita Island, Venezuela. Ciencias Marinas, vol. 21, no. 4, pp. 387-399. http://dx.doi.org/10.7773/cm.v21i4.1004.

KNOFF, M., LUQUE, J.L. and AMATO, J.F., 1997. Community ecology of the metazoan parasites of grey mullets, Mugil platanus (Osteichyes: Mugilidae) from the litoral of the state of Rio de Janeiro, Brazil, Revista Brasileira de Biologia $=$. Brazilian Journal of Biology = Revista Brasileira de Biologia, vol. 8, no. 3, pp. 441-454. PMid:9430918.

LESSA, R., DUARTE-NETO, P., MORIZE, E. and MACIEL, R., 2008. Otolith microstructure analysis with OTC validation confirms age overestimation in Atlantic thread herring Opisthonema oglinum from north-eastern Brazil. Journal of Fish Biology, vol. 73, no. 7, pp. 1690-1700. http://dx.doi.org/10.1111/j.10958649.2008.02043.x.

LUQUE, J.L. and ALVES, D.R., 2001. Ecologia das comunidades de metazoários parasitos, do xaréu, Caranx hippos (Linnaeus) e do xerelete, Caranx latus Agassiz (Osteichthyes, Carangidae) do litoral do estado do Rio de Janeiro, Brasil. Revista Brasileira de Zoologia, vol. 18, no. 2, pp. 399-410. http://dx.doi.org/10.1590/ S0101-81752001000200011.

LUQUE, J.L. and CHAVES, N.D., 1999. Ecologia da comunidade de metazoários parasitos da anchova Pomatomus saltator (Linnaeus) (Osteichthyes, Pomatomidae) do litoral do Estado do Rio de Janeiro, Brasil. Revista Brasileira de Zoologia, vol. 16, no. 3, pp. 711-723. http://dx.doi.org/10.1590/S0101-81751999000300010.

LUQUE, J.L. and TAVARES, L.E.R., 2007. Checklist of Copepoda associated with fishes from Brazil. Zootaxa, vol. 1579, no. 1, pp. 1-39. http://dx.doi.org/10.11646/zootaxa.1579.1.1.

LUQUE, J.L., AMATO, J.F.R. and TAKEMOTO, R.M., 1996. Comparative analysis of the communities of metazoan parasites of Orthopristis ruber and Haemulon steindachneri (Osteichthyes: 
Haemulidae) from the southeastern Brazilian littoral: I. structure and influence of the size and sex of hosts. Brazilian Journal of Biology $=$ Revista Brasileira de Biologia, vol. 56, pp. 279-292.

LUQUE, J.L., VIEIRA, F.M., TAKEMOTO, R.M., PAVANELLI, G.C. and EIRAS, J.C., 2013. Checklist of Crustacea parasitizing fishes from Brazil. Check List, vol. 9, no. 6, pp. 1449-1470. http:// dx.doi.org/10.15560/9.6.1449.

LUQUE, J.L., VIÑAS, R.A., PARAGUASSÚ, A.R. and ALVES, D.R., 2000. Metazoários Parasitos das Sardinhas Sardinella brasilienses e Harengula clupeola (Ostichthlyes, Clupeidae) do litoral do Estado do Rio de Janeiro, Brasil. Revista Universidade Rural. Série Ciências da Vida, vol. 22, pp. 71-76.

MOREIRA, J., PASCHOAL, F., CEZAR, A.D. and LUQUE, J.L., 2015. Community ecology of the metazoan parasites of Brazilian sardinella, Sardinella brasiliensis (Steindachner, 1879) (Actinopterygii: Clupeidae) from the coastal zone of the State of Rio de Janeiro, Brazil. Brazilian Journal of Biology $=$ Revista Brasileira de Biologia, vol. 75, no. 3, pp. 736-741. http://dx.doi. org/10.1590/1519-6984.00114. PMid:26465733.

NELSON, J.S., 2006. Fishes of the world. 4th ed. New York: John Wiley and Sons, $601 \mathrm{p}$.

PALM, H., 1997. Trypanorhynch Cestodes of Commercial Fishes from Northeast Brazilian Coastal Waters. Memórias do Instituto Oswaldo Cruz, vol. 92, no. 1, pp. 69-79.

PFEIFFER, W.C., LACERDA, L.D., FISZMAN, M. and LIMA, N.R.W., 1985. Metais pesados no pescado da Baía de Sepetiba. Ciencia e Cultura, vol. 37, no. 2, pp. 297-302.

POULIN, R., 1993. The disparity between observed and uniform distributions: a new look at parasite aggregation. International Journal for Parasitology, vol. 23, no. 7, pp. 937-944. http://dx.doi. org/10.1016/0020-7519(93)90060-C. PMid:8106186.

POULIN, R., 1995. Phylogeny, ecology, and richness of parasite communities in vertebrates. Ecological Monographs, vol. 65, no. 3, pp. 283-302. http://dx.doi.org/10.2307/2937061.

POULIN, R., 2001a. Another look at the richness of helminth communities in tropical freshwater fish. Journal of Biogeography, vol. 28, no. 6, pp. 737-743. http://dx.doi.org/10.1046/j.13652699.2001.00570.x.

POULIN, R., 2001b. Interactions between species and the structure of helminth communities. Parasitology, vol. 122, no. S1, (suppl.), pp. S3-S11. http://dx.doi.org/10.1017/S0031182000016991. PMid:11442194.

ROHDE, K., HAYWARD, C. and HEAP, M., 1995. Aspects of the ecology of metazoan ectoparasites of marine fishes. International Journal for Parasitology, vol. 25, no. 8, pp. 945-970. http://dx.doi. org/10.1016/0020-7519(95)00015-T. PMid:8550295.

RÓZSA, L., REICZIGEL, J. and MAJOROS, G., 2000. Quantifying parasites in samples of hosts. The Journal of Parasitology, vol. 86 , no. 2 , pp. 228-232. http://dx.doi.org/10.1645/00223395(2000)086[0228:QPISOH]2.0.CO;2. PMid:10780537.

SANTOS, C.P. and KOHN, A., 1992. Description of Cribomazocraes travassosi n. sp. (Monogenea: Mazocraeidae), a fish parasite from the Atlantic Ocean. Memorias do Instituto Oswaldo Cruz, vol. 87, suppl. 1, pp. 247-250. http://dx.doi.org/10.1590/S007402761992000500046.

SILVA, L.O., LUQUE, J.L., ALVES, D.R. and PARAGUASSÚ, A.R., 2000. Ecologia da comunidade de metazoários parasitos do peixe-espada Trichiurus lepturus Linnaeus (Osteichthyes, Trichiuridae) do litoral do Estado do Rio de Janeiro, Brasil. Revista Brasileira de Zoologia, vol. 2, no. 2, pp. 115-133.

TAKEMOTO, R.M., AMATO, J.F.R. and LUQUE, J.L., 1996. Comparative analysis of the metazoan parasite communities of leatherjackets, Oligoplites palometa, O. saurus, and O. saliens (Osteichtyles: Carangidae) from Sepetiba Bay, Rio de Janeiro, Brazil. Brazilian journal of biology $=$ Revista brasleira de biologia, vol. 56 , no. 4 , pp. 639-650.

TAVARES, L.E.R. and LUQUE, J.L., 2004. Community ecology of metazoan parasites of the later juvenile common snook Centropomus undecimalis (Osteichthyes: Centropomidae) from the coastal zone of the state of Rio de Janeiro, Brazil. Brazilian Journal of Biology $=$ Revista Brasileira de Biologia, vol. 64, no. 3a, pp. 523-529. http://dx.doi.org/10.1590/S1519-69842004000300015. PMid:15622849.

TAVARES, L.E.R., LUQUE, J.L. and BICUDO, A.J., 2004. Metazoan parasites of Brazilian menhaden Brevoortia aurea (Spix \& Agassiz, 1829) (Osteichthyes: Clupeidae) from the coastal zone of the State of Rio de Janeiro, Brazil. Brazilian Journal of Biology $=$ Revista Brasileira de Biologia, vol. 64, no. 3A, pp. 553-554. http://dx.doi.org/10.1590/S1519-69842004000300019. PMid:15622853.

TAVARES, L.E.R., LUQUE, J.L. and BICUDO, A.J., 2005. Community ecology of the metazoan parasites of anchovy Anchoa tricolor (Osteichthyes: Engraulidae) from the coastal zone of the State of Rio de Janeiro, Brazil. Brazilian Journal of Biology = Revista Brasileira de Biologia, vol. 65, no. 3, pp. 533-540. http:// dx.doi.org/10.1590/S1519-69842005000300019. PMid:16341432.

VEGA-CENDEJAS, M.E., HERNANDEZ, M. and ARREGUINSANCHEZ, F., 1997. Trophic interrelations in a beach seine fishery from the northwestern coast of the Yucatan peninsula, Mexico. Journal of Fish Biology, vol. 44, no. 4, pp. 647-659. http://dx.doi. org/10.1111/j.1095-8649.1994.tb01241.x.

VON ZUBEN, C.J., 1997. Implicações da agregação espacial de parasitas para a dinâmica populacional na interação hospedeiroparasita. Revista de Saude Publica, vol. 31, no. 5, pp. 523-530. http:// dx.doi.org/10.1590/S0034-89101997000600014. PMid:9629733.

ZAR, J.H., 1996. Biostatistical analysis. 3rd ed. New Jersey: Prentice-Hall, 662 p. 